\title{
Successful pregnancy in an ovarian Sertoli-Leydig cell tumor patient with heterologous elements: case report and literature review
}

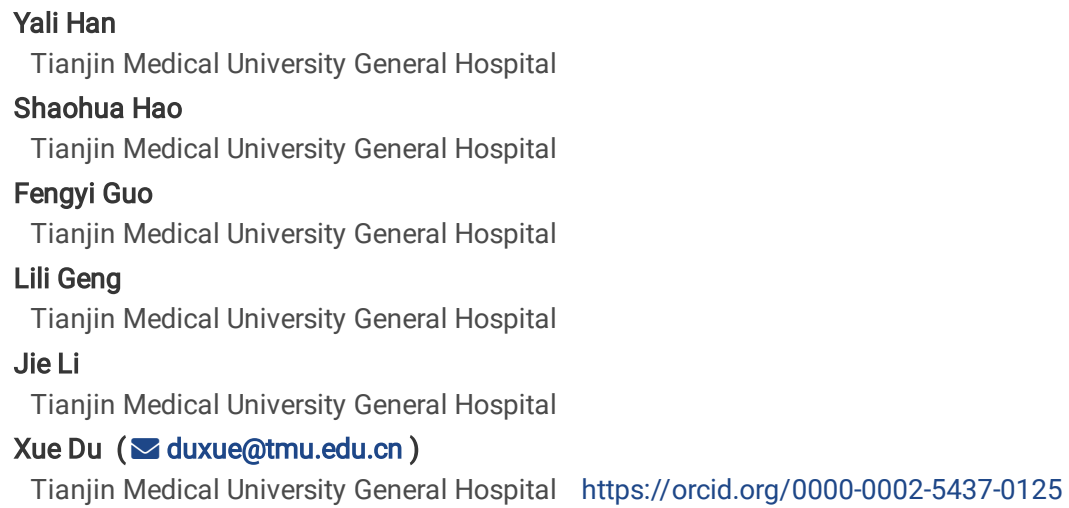

\section{Case Report}

Keywords: Sertoli-Leydig cell tumors, heterologous elements, mucinous epithelium, liposarcoma, alpha-fetoprotein, pregnancy

Posted Date: May 11th, 2021

DOI: https://doi.org/10.21203/rs.3.rs-506332/v1

License: (c) (1) This work is licensed under a Creative Commons Attribution 4.0 International License. Read Full License 


\section{Abstract}

Background: Ovarian Sertoli-Leydig cell tumor (SLCT) is an extremely rare sex-cord stromal tumor of the ovary. Notably, ovarian SLCT with mucinous epithelium and liposarcoma is even rarer.There is also evidence that the presence of heterologous elements is a poor prognostic factor of SLCTs. Very often, ovarian SLCT patient first presents with high androgen levels and sometimes a clarge mass in the pelvic cavity, making it difficult for early diagnosis.

Case presentation: In this study, we reported a SLCT patient with heterologous elements and elevated the serum alpha-fetoprotein (AFP) levels. A 22-year old nulliparous female was first admitted with clinical symptoms of abdominal pain, a large mass in the pelvic cavity and elevated serum AFP levels, and for this she underwent left adnexectomy. Pathological examination revealed ovarian SLCT with intestinal type mucinous epithelium and liposarcoma, and immunohistochemical staining revealed positive staining for AFP in the intestinal type mucinous epithelium. The patient became pregnant naturally four years later, but SLCT was found in the opposite ovary with liposarcoma but no significant increase in serum AFP levels.Further, we reviewed the literature in order to improve preoperative diagnosis and evaluation of long-term prognosis of SLCTs with heterologous elements.

Conclusion: The increase in serum AFP levels could be used for preoperative diagnosis of the presence of heterologous elements and the postoperative recurrence.

\section{Background}

Ovarian SLCT is an extremely rare sex-cord stromal tumor of the ovary occurring predominantly in young females, and its clinical symptoms and signs are associated with virilization due to androgen excess or space occupying lesions in the pelvic cavity[1-3].However, most SLCT patients with heterologous elements were first admitted to the hospital for abdominal signs and symptoms caused by growth or rupture of ovarian tumors but rarely for virilization[4-6]. Ovarian SLCTs can be subdivided into well, moderately and poorly differentiated SLCTs with or without heterologous elements and/or retiform pattern, and heterologous elements are often present in moderately and poorly differentiated SLCTs[7].Other cell types except Sertoli cells, Leydig cells and gonadal stroma that are native to the ovary are termed heterologous.Prat et al.[8] found that the presence of heterologous elements, especially mesenchymal components, might be associated with a much worse prognosis. Here, we reported an extremely rare case of moderately or poorly differentiated SLCT with mucinous epithelium and liposarcoma and also reviewed the literature.

\section{Case Report}

This 22-year old female was single but reported a history of sexual activity, and she was once hospitalized in 2015 with complaints of intermittent pain in the right lower quadrant of the abdomen for more than 1 month but acute exacerbation of pain accompanied with headache and nausea for $1 \mathrm{~h}$. Prior to visiting our hospital, the patient received anti-inflammatory treatment for appendicitis in another hospital, but no improvement of her symptoms was observed. On admission physical examination showed no obvious virilizing signs; localized tenderness over the abdomen, especially in the right lower quadrant of the abdomen, rebound tenderness (+), muscle tone (+), shifting dullness ( \pm ); normal uterine size, a large palpable cystic mass in the right adnexa whose size was

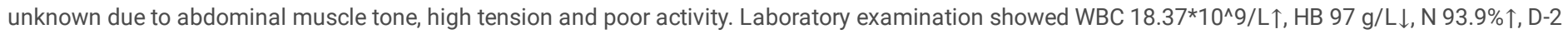
dimer $>10000 \mathrm{ng} / \mathrm{ml}$, AFP $442.60 \mathrm{ng} / \mathrm{ml} \uparrow$, CA125 $92.80 \mathrm{U} / \mathrm{ml} \uparrow$. The examination of six sex hormones (follicle-stimulating hormone, luteinizing hormone, estradiol, progesterone, testosterone and prolactin) showed early follicular phase, $T 47.32 \mathrm{ng} / \mathrm{dl}$, but no other abnormalities. The ultrasonic examination (Fig. $1 \mathrm{~A}$ and $1 \mathrm{~B}$ ) showed a solid-cystic mass of $14.2 * 10.5 * 9.7 \mathrm{~cm}$ in the right lower quadrant of the abdomen and another solid-cystic mass of $10.7 * 10.2 * 9.1$ $\mathrm{cm}$ in the right upper quadrant of the abdomen, as well as a moderate amount of ascites. Thus, tumor torsion or rupture was suspected in the pelvic cavity. Laparotomy was performed immediately, which revealed the presence of $1000 \mathrm{ml}$ of blood in the pelvic and abdominal cavity and a solid-cystic mass of approximately $15^{\star} 12^{\star} 11 \mathrm{~cm}$ with prominent surface vessels in the left ovary. The capsule of the mass in the right lower quadrant of the abdomen was ruptured, and some tumor tissues and a large quantity of old blood were covered by greater omentum and adhered to the wall of the right pelvis. Neovascularization was observed at the adhesion sites, and the wrappage was about $17 \star 10 \star 8 \mathrm{~cm}$. The adhesion was separated and the left adnexa and the tumor covered by the greater omentum were excised. Intraoperative pathological examination of frozen sections revealed a malignant tumor of germ cell origin, and 7 days later the pathological examination of paraffin-embedded sections revealed poorly differentiated SLCT of the left ovary with mucinous epithelium and liposarcoma (Fig. 2A-F). The final diagnosis was stage 『c SLCT of the left ovary. Chemotherapy with Docetaxel and Cisplatin (DP) was administered for 6 cycles, and triptorelin ( $3.75 \mathrm{mg}$ per time for 3 cycles) was intramuscularly injected every 28 days before and during chemotherapy to preserve the fertility of the patient, and no abnormality was seen. Serum AFP levels before and after operation were monitored (Fig. 3), and tumor marker and B-Ultrasound examination were normal during the 2-year follow up. However, the patient was lost to follow up for 1 year.

The patient became pregnant naturally in 2018 but presented with a cystic mass of $3.3^{\star} 2.8 \mathrm{~cm}$ in the right adnexa during the early pregnancy. The ultrasonography performed at 27 and 37 weeks of gestation (Fig. 1C and 1D) showed a solid mass of approximately $7.0 * 7.3 * 5.7 \mathrm{~cm}$ and a solid-cystic (mainly solid) mass of approximately $13.4 * 10.7 * 8.4 \mathrm{~cm}$ in the right adnexa. The mass was growing gradually, AFP $166.54 \uparrow \mathrm{ng} / \mathrm{ml}$, and other indicators were normal. Cesarean section was performed at $38+1$ weeks of gestation, and a living baby was delivered smoothly. Intraoperative exploration revealed a purple black solid-cystic mass of approximately $18 * 16 * 10 \mathrm{~cm}$ in the right ovary, which was then removed. It looked like erodible meat and had multilocular cysts with rich vessels (Fig. 4). Intraoperative pathological examination of frozen sections revealed a malignant tumor of the right ovary origin. The family members of the patient were informed and asked to evaluate future treatment strategies. The pathological examination of paraffin-embedded sections (Fig. 2G-I) revealed moderately or poorly differentiated SLCT of the right ovary with liposarcoma. The immunohistochemical staining revealed positive staining for CD99, ainhibin, MDM2 and CDK4 in tumor cells. The final diagnosis was stage $₫ \mathrm{c}$ SLCT. However, the patient refused further surgical intervention and chemotherapy. No obvious solid-cystic mass was seen in the left adnexa, and the right ovary was $22{ }^{*} 1.5 \mathrm{~cm}$ with normal echo, The serum AFP levels were within the normal range (Fig. 3). The patient was followed up for 6 months till now and would be further followed up. 


\section{Discussion}

SLCT is also referred to as androblastoma, and it is an extremely uncommon neoplasm, accounting for only about $1 \%$ of all ovarian sex cord stromal tumors and $0.2-0.5 \%$ of all ovarian tumorsc ${ }^{[9]}$. It occurs more often in young females between 20 and 30 years of age with an average age of 25 years and occasionally in children and menopausal women. SLCT was even reported in a 12-month-old infant[10], and the younger the patients, the lower the differentiation degree ${ }^{[1,2]}$. SLCT typically occurs unilaterally, mostly confined to the ovary and seldom form distant metastases $(2.5 \%)$ to other organsc ${ }^{[11,12,7}$,

1]. As most ovarian SLCT cells can synthesize androgens, approximately $25-77 \%$ of patients may present with defeminization (e.g., oligomenorrhea, amenorrhea and breast atrophy) followed by virilization (e.g., hoarseness of voice, hirsutism, facial acne and clitoromegaly) ${ }^{[13]}$.Chang et al. ${ }^{[14]}$ showed that a serum testosterone level of $\$ 6.9 \mathrm{nmol} / \mathrm{L}(200 \mathrm{ng} / \mathrm{dL})$ indicated the presence of androgen-producing tumors mostly in the ovary or adrenal gland. Ovarian SLCTs should be considered in virilized patients with markedly elevated serum testosterone levels and space occupying lesions of the ovary. However, some patients may have no endocrine abnormalities but have a tumor diameter of $>10 \mathrm{~cm}$, poor pathological differentiation and a high rupture risk, and these patients are often admitted due to abdominal distension and pain ${ }^{[7]}$. However, patients requiring emergency surgery for acute abdominal pain account for < $15 \%$ of all ovarian SLCT patients, which can be caused by ovarian torsion, rupture or hemorrhage of the mass ${ }^{[15]}$. In our case, the young female was hospitalized for intermittent pain in the right lower quadrant of the abdomen and the presence of a large mass in the pelvic cavity, but no obvious manifestations of high androgen levels and hyperandrogenism were noted. Intraoperative exploration showed that the tumor was ruptured and wrapped, and postoperative pathological examination showed moderately or poorly differentiated ovarian SLCT with heterologous elements.Manifestations of high androgen levels are rarely reported in SLCT patients with heterologous elements, and in most circumstances, ovarian SLCT patients are first admitted to the hospital for abdominal signs and symptoms caused by ovarian tumors ${ }^{[4-6]}$, which is in agreement with the case reported here.

However, although the presence of clinical manifestations of high androgen levels in some patients contributes to preoperative diagnosis of SLCT, the diagnosis of SLCT is usually established by histopathological examination. Grossly, it appears as a large solid, cystic or solid-cystic mass ${ }^{[1]}$. According to the differentiation of tubular structures composed of Sertoli cells, the percentage of primordial gonads, the number of Leydig cells and the presence or absence of heterologous elements, SLCTs can be subdivided into well, moderately and poorly differentiated SLCTs with or without heterologous elements and/or retiform pattern, and heterologous elements are more likely to be present in moderately or poorly differentiated tumors or tumors with a retiform patternc ${ }^{[10,16,1,17,12]}$. Sertoli cells can secrete high amounts of estrogen and small amounts of progesterone and androgen, while Leydig cells can secrete high amounts of androgen and small amounts of estrogen and progesterone. Thus, the clinical manifestations of SLCTs are closely associated with the percentage of different histological types of tumors and the hormones secreted by tumor cells. In our case, the patient had only a small number of Leydig cells but a large number of Sertoli cells, which agreed well with the observation of no significant increase in androgen levels in this patient. The combination of H\&E and immunohistochemical staining is considered the most reliable method for diagnosis of SLCTs. Microscopic examination revealed many eosinophilic Leydig cells interspersed with Sertoli cells in small clusters, and immunohistochemical staining revealed positive staining for CK, CD99, CD10, Vimentin and a-inhibin, indicating the possibility of ovarian SLCT. Sertoli cells were round shaped with scanty cytoplasm, deeply stained nuclei, nuclear pleomorphism, no obvious tubular structure and a flake distribution, which was determined to be moderately or poorly differentiated ovarian SLCT. In addition, two heterologous elements, mucinous epithelium and liposarcoma, were also identified. Notably, SLCT with liposarcoma has rarely been reported in the literature.

Heterologous elements are present in approximately $20 \%$ of ovarian SLCTs and can be further separated into endodermal elements and mesenchymal elements[18].The former are represented by endodermal type mucin-secreting epithelium and hepatocyte-like cells, while the latter are represented by immature cartilage and skeletal muscles.Mucinous epithelium is the most common heterologous element accounting for $20 \%$ of moderately differentiated ovarian SLCTs. The intestinal type mucinous epithelium is predominant over other types of mucinous epithelium, which is commonly accompanied by goblet cells and occasionally by argyrophil cells and exhibits neuroendocrine differentiation[1, 8]. Heterologous elements such as skeletal muscle, bone and cartilage are rare, and hepatocyte-like cells are even rarer[19].However, the histogenesis of heterologous elements remains controversial and not fully understood, which may be related to the mesenchymal metaplasia of tumour cells ${ }^{[20]}$. The tumor may also be a mixed Mullerian tumor or derived from teratoma[21].As these heterologous elements can be derived from different embryonic layers, the morphological changes of SLCTs are more extensive than any other ovarian tumors except teratoma[22].In our case, the pathological examination after the first surgery revealed the presence of goblet cells intermingled with tall columnar cells, implying the presence of intestinal type mucinous epithelium. A large number of naive adipocytes were also observed and their nuclei were pushed to the periphery of the cell by vacuoles, giving the cell a typical signet ring appearance. Cells were round or ellipse shaped with chicken feet-like capillary networks and occasionally lipoblasts, implying the presence of liposarcoma. The pathological examination after the second surgery showed no mucinous epithelium, and HE staining showed some fat-like cells with deeply stained nuclei. The immunohistochemical staining showed positive staining for MDM2 and CDK4, with a sensitivity of $80-97 \%$ and a specificity of $64-93 \%$ for MDM2 and a sensitivity of $68.9-92 \%$ and a specificity of $95-100 \%$ for CDK4, respectively[23-25].For these reasons, the patient was diagnosed to have only liposarcoma. Notably, this heterologous element has rarely been reported in the literature.

Some patients would visit the hospital for abdominal pain or mass, and it is difficult to make an early diagnosis of ovarian SLCTs. However, serum AFP levels may be elevated in moderately or poorly differentiated SLCTs or SLCTs with heterologous elements[26]. AFP is a fetal globulin synthesized by the fetal liver and yolk sac during early pregnancy, which is often considered a marker of primary liver cancer. However, serum AFP levels can also be elevated in some gynecological diseases, germ cell tumors and immature teratoma, especially in endodermal sinus tumor, which can be used for preoperative diagnosis and evaluation of therapeutic efficacy and prognosis[27-30]. The increase in serum AFP levels in ovarian SLCTs can be related to various cells such as sertoli cells, leydig cells, gastrointestinal type epithelium and hepatocytes[31], but the mechanism remains largely unknown.WATANABE et al.[31] first reported heterologous gastrointestinal epithelium expression of AFP in a poorly differentiated SLCT, which was also the first case of AFP production by heterologous gastrointestinal epithelium in SLCT. We reviewed reported cases of SLCTs with heterologous elements and elevated serum AFP levels, including the age at the time of diagnosis, causes of first hospitalization, surgery type, SLCT type, presence or absence of heterologous elements, immunohistochemical staining of AFP, serum AFP levels before and after surgery, androgen levels before and after surgery, postoperative chemotherapy and follow-up outcomes. 
A total of 25 SLCT patients (including our case) with heterologous elements and elevated serum AFP levels were identified in PUBMED (Table 1). All of these patients presented with elevated serum AFP levels, and immunohistochemical staining showed positive staining for AFP in 92\% (23/25) patients and negative staining for AFP in $8 \%(2 / 25)$ patients, respectively. Leydig cells, Sertoli cells, gastrointestinal type mucinous epithelium and hepatocytes were positively stained in $16 \%(4 / 25), 8 \%(2 / 25), 24 \%(6 / 25)$ and $44 \%(11 / 25)$ patients, respectively, indicating that the increase in serum AFP levels might be associated with AFP in tumor cells. It is important to note that serum AFP levels are elevated to $>1000 \mathrm{ng} / \mathrm{ml}$ in patients with AFP-positive Sertoli cells and hepatocytes.

However, it is possible that the so-called AFP-positive Sertoli cells in SLCT are basically areas of primitive heterologous intestinal elements, which is similar to the AFP-positive endodermal elements in teratoma[5].The negative immunohistochemical staining for AFP can also be attributed to the presence of only a small amount of heterologous elements[32].In our case, the serum AFP levels were elevated to $₫ 400 \mathrm{ng} / \mathrm{ml}$ before the first surgery, and immunohistochemical staining showed negative staining for AFP in Sertoli and Leydig cells but strongly positive staining for AFP in mucinous epithelium (Fig. 5). The serum AFP levels returned to normal within half a year after surgery with no evidence of recurrence. Thus, the increase in serum AFP levels may be associated with the presence of mucinous epithelium. The patient became pregnant naturally 4 years later, but recurrence occurred in the opposite ovary with a serum AFP level of about $160 \mathrm{ng} / \mathrm{ml}$. The pathological examination showed no mucinous epithelium. However, the serum AFP levels of pregnant women may also increase due to the presence of the fetus, which often becomes detectable at 16 weeks of gestation, reaches a maximum at 32-34 weeks of gestation, and decreases to normal after childbirth. Note that the serum AFP levels would not exceed $400 \mathrm{ng} / \mathrm{ml}$. The results at 4-month follow up showed neither abnormal symptoms nor elevated serum AFP levels. For this reason, the increase in serum AFP levels during the gestation could not be caused by tumors, but it is likely to be the physiological characteristics of the gestation period. The review of the 25 cases also showed that the serum AFP levels were reduced to normal after surgery, but increased again with tumor recurrence in 2 cases. Thus, the increase in serum AFP levels is likely to be related to the presence of heterologous elements in tumor tissues. The increase in serum AFP levels may have important implications for preoperative determination of the presence of heterologous elements and evaluation of the prognosis of SLCTs. 
Table 1

Cases of SLCT Associated With Raised Serum AFP and heterologous elements (Literature Review)

\begin{tabular}{|c|c|c|c|c|c|c|c|c|c|c|}
\hline References & $\begin{array}{l}\text { No. } \\
\text { Case }\end{array}$ & Age & Clinical & Sur & $\begin{array}{l}\text { G } \\
(\mathrm{cm})\end{array}$ & $\begin{array}{l}\text { Differ } \\
\text { /AFP(+) }\end{array}$ & Heter & $\begin{array}{l}\text { T Pre\& Post } \\
(\mathrm{ng} / \mathrm{dl})\end{array}$ & $\begin{array}{l}\text { AFP Pre\& } \\
\text { Post } \\
\text { (ng/mL) }\end{array}$ & Chemo \\
\hline $\begin{array}{l}\text { Singh et } \\
\text { al.[1] }\end{array}$ & 1 & $17 y$ & $\begin{array}{l}\text { secondary } \\
\text { amenorrhea, } \\
\text { hirsuitism and } \\
\text { hoarseness of voice } \\
\text { 1yr }\end{array}$ & NA & $\begin{array}{l}10 \times 6 \times 5 \\
C S\end{array}$ & $\begin{array}{l}\text { MD } \\
\text { /Leydig }\end{array}$ & $\begin{array}{l}\text { GIEP with } \\
\text { dysplasia; R- } \\
\text { Sar }\end{array}$ & $\begin{array}{l}\text { Pre: } 350 \\
\text { Post 6W: } \\
\text { 140; }\end{array}$ & $\begin{array}{l}\text { Pre : 40; } \\
\text { Post 6W: } \\
14 ;\end{array}$ & NA \\
\hline $\begin{array}{l}\text { Watanabe } \\
\text { et al.[2] }\end{array}$ & 1 & $20 y$ & $\begin{array}{l}\text { abdominal } \\
\text { enlargement;irregular } \\
\text { menstrual cycles for } \\
\text { 1y }\end{array}$ & RSO & 30max;CS & $\begin{array}{l}\text { NA } \\
\text { /GIEP }\end{array}$ & $\cdot$ GIEP & NA & $\begin{array}{l}\text { Pre: } 306 \\
\text { Post: } \\
\text { normal }\end{array}$ & $\begin{array}{l}\text { Taxol; } \\
\text { carboplá }\end{array}$ \\
\hline $\begin{array}{l}\text { Singh et } \\
\text { al.[3] }\end{array}$ & 1 & $12 \mathrm{y}$ & $\begin{array}{l}\text { slowly worsening } \\
\text { abdominal pain of } \\
2 w\end{array}$ & RSO & $\begin{array}{l}11.7 x \\
10.1 x \\
7.9 ; C S ; \\
\text { confined } \\
\text { R }\end{array}$ & $\begin{array}{l}\text { PD } \\
\text { /Leydig }\end{array}$ & $\begin{array}{l}\text { R-Sar and } \\
\text { glandular }\end{array}$ & $\begin{array}{l}\text { Pre: normal } \\
\text { Post: } \\
\text { normal }\end{array}$ & $\begin{array}{l}\text { Pre: } 77.1 \\
\text { Post } 6 \mathrm{~W}: \\
4.3\end{array}$ & $\begin{array}{l}\text { BEPx4 } \\
\text { cycles }\end{array}$ \\
\hline $\begin{array}{l}\text { Al- } \\
\text { Hussaini } \\
\text { et al.[4] }\end{array}$ & 6 & $\begin{array}{l}27 y \\
20 y \\
15 y \\
18 y \\
18 \text { year } \\
15 y\end{array}$ & NA & NA & $\begin{array}{l}22 \\
11 \\
27 \\
14 \\
13 \\
8\end{array}$ & $\begin{array}{l}\text { PD/IME } \\
\text { MD/IME } \\
\text { PD/IME } \\
\text { MD/IME } \\
\text { Retiform/Leydig } \\
\text { MD/None }\end{array}$ & $\begin{array}{l}\text { IME } \\
\text { IME } \\
\text { IME } \\
\text { IME } \\
\text { IME } \\
\text { IME }\end{array}$ & NA & $\begin{array}{l}\text { Pre:411 } \\
\text { Pre:100 } \\
\text { Pre:137 } \\
\text { Pre:685 } \\
\text { Pre:35.3 } \\
\text { Pre:185 } \\
\text { (Post:All } \\
\text { DN) }\end{array}$ & NA \\
\hline $\begin{array}{l}\text { Motoyama } \\
\text { et al.[5] }\end{array}$ & 1 & $18 y$ & $\begin{array}{l}\text { amenorrhea } 6 \\
\text { yr;virilism }\end{array}$ & LSO & $40 \times 20 \times 15$ & $\begin{array}{l}\text { MD + Retiform } \\
\text { /Sertoli cells }\end{array}$ & IME & $\begin{array}{l}\text { Pre:520 } \\
\text { Post:normal }\end{array}$ & $\begin{array}{l}\text { Pre:1443 } \\
\text { Post:normal }\end{array}$ & $\begin{array}{l}\text { BVCX3 } \\
\text { cycles }\end{array}$ \\
\hline $\begin{array}{l}\text { lkota et al. } \\
\text { [6] }\end{array}$ & 1 & $12 \mathrm{y}$ & $\begin{array}{l}\text { appetite loss, } \\
\text { diarrhea, abdominal } \\
\text { enlargement } \\
1 \mathrm{M}\end{array}$ & LSO, & $\begin{array}{l}27 \times 15 \times \\
10\end{array}$ & $\begin{array}{l}\text { MPD } \\
\text { /immature } \\
\text { hepat }\end{array}$ & $\begin{array}{l}\text { GIEP, } \\
\text { immature } \\
\text { hepat }\end{array}$ & $\begin{array}{l}\text { Pre:0.31 } \\
\text { Post: NA }\end{array}$ & $\begin{array}{l}\text { Pre: } 1349.4 \\
\text { Post } \\
\text { 10W:normal }\end{array}$ & $\begin{array}{l}\text { BEPx3 } \\
\text { cycles }\end{array}$ \\
\hline $\begin{array}{l}\text { Young et } \\
\text { al.[7] }\end{array}$ & 1 & $13 y$ & $\begin{array}{l}\text { Abdominal swelling } \\
\text { and pain }\end{array}$ & BSO & $\begin{array}{l}30 \times 20 x \\
10\end{array}$ & $\begin{array}{l}\text { PD with } \\
\text { Retiform } \\
\text { /hepat }\end{array}$ & $\begin{array}{l}\text { IME, } \\
\text { hepat, } \\
\text { SM }\end{array}$ & NA & $\begin{array}{l}\text { Pre:14000 } \\
\text { Post 4M:25 } \\
\text { Post } \\
\text { 7M:3800 }\end{array}$ & $\begin{array}{l}\text { BVCx2 } \\
\text { cycles n } \\
\text { Cy-actD- } \\
\text { x2 cycle }\end{array}$ \\
\hline $\begin{array}{l}\text { Chadha et } \\
\text { al.[8] }\end{array}$ & 2 & $\begin{array}{l}16 \mathrm{y} \\
11 \mathrm{M}\end{array}$ & $\begin{array}{l}\text { Amenorrhea 4M } \\
\text { Acute abdominal } \\
\text { pain }\end{array}$ & $\begin{array}{l}\text { BSO } \\
\text { RSO }\end{array}$ & $\begin{array}{l}12 \times 11 \\
\times 16, C S \\
10 \times 9 \times 6\end{array}$ & $\begin{array}{l}\text { NA } \\
\text { /Sertoli cell } \\
\text { Retiform } \\
\text { / hepat }\end{array}$ & $\begin{array}{l}\text { GIEP } \\
\text { Resembling } \\
\text { hepat cell }\end{array}$ & $\begin{array}{l}\text { normal } \\
\text { NA }\end{array}$ & $\begin{array}{l}\text { Pre:4500 } \\
\text { Post:430 } \\
\text { Pre:1500 } \\
\text { Post :200 } \\
\text { Post } \\
\text { 4M:3500 } \\
\text { Post } \\
\text { 5M:7000 } \\
\text { Post } \\
\text { 6M:11700 } \\
\text { Post 2nd } \\
\text { operation } \\
\text { 4d:9000 }\end{array}$ & $\begin{array}{l}\text { NA } \\
\text { Cy-actD- } \\
\text { Vx10 } \\
\text { cycles }\end{array}$ \\
\hline $\begin{array}{l}\text { Liang et al. } \\
\text { [9] }\end{array}$ & 1 & $15 y$ & constipation $8 \mathrm{M}$ & LSO & $\begin{array}{l}26 \times 24 x \\
14\end{array}$ & $\begin{array}{l}\text { NA } \\
\text { / hepat } \\
\text { differentiation }\end{array}$ & $\begin{array}{l}\text { mucinous } \\
\text { epithelium, } \\
\text { hepat differ }\end{array}$ & Normal & $\begin{array}{l}\text { Pre: } \\
\text { elevated } \\
\text { Post:NA }\end{array}$ & NA \\
\hline
\end{tabular}




\begin{tabular}{|c|c|c|c|c|c|c|c|c|c|c|}
\hline References & $\begin{array}{l}\text { No. } \\
\text { Case }\end{array}$ & Age & Clinical & Sur & $\begin{array}{l}\text { G } \\
(\mathrm{cm})\end{array}$ & $\begin{array}{l}\text { Differ } \\
\text { /AFP(+) }\end{array}$ & Heter & $\begin{array}{l}\text { T Pre\& Post } \\
\text { (ng/dl) }\end{array}$ & $\begin{array}{l}\text { AFP Pre\& } \\
\text { Post } \\
\text { (ng/mL) }\end{array}$ & Chemo \\
\hline $\begin{array}{l}\text { Mooney et } \\
\text { al.[10] }\end{array}$ & 5 & $\begin{array}{l}44 \\
74 \\
18 \\
23 \\
15\end{array}$ & NA & NA & NA & $\begin{array}{l}\text { Retiform/hepat } \\
M D+ \\
\text { Retiform/hepat } \\
\text { PD + Retiform/ } \\
\text { hepat } \\
M D+ \\
\text { Retiform/hepat } \\
\text { PD + Retiform/ } \\
\text { hepat }\end{array}$ & $\begin{array}{l}\text { Hepat } \\
\text { Hepat + sar } \\
\text { Hepat + } \\
\text { cartilage } \\
\text { Hepat } \\
\text { Hepat + Sar } \\
\text { recurrent }\end{array}$ & NA & $\begin{array}{l}\text { Pre:NA but } \\
\text { elevated } \\
\text { Post:NA }\end{array}$ & NA \\
\hline $\begin{array}{l}\text { Horta et al. } \\
\text { [11] }\end{array}$ & 1 & $19 y$ & $\begin{array}{l}\text { diffuse abdominal } \\
\text { pain and bloating }\end{array}$ & RSO & $\begin{array}{l}8.2 \times 7.5 \times \\
6.5, \mathrm{CS}\end{array}$ & $\begin{array}{l}\text { PD } \\
\text { /Not found }\end{array}$ & IME & NA & $\begin{array}{l}\text { Pre:46.3 } \\
\text { Post:normal }\end{array}$ & BEP \\
\hline $\begin{array}{l}\text { 20.Jang et } \\
\text { al.[12] }\end{array}$ & 1 & 26 & $\begin{array}{l}\text { Amenorrhea } \\
3 \mathrm{M} \text {,masculine voice, } \\
\text { pelvic mass }\end{array}$ & NA & $\begin{array}{l}11 \times 9 \times 9 \\
, C S, \text { filled } \\
\text { with } \\
\text { mucoid } \\
\text { material }\end{array}$ & $\begin{array}{l}\text { MD + retiform } \\
\text { /Leydig cell }\end{array}$ & IME & $\begin{array}{l}\text { Pre:90 } \\
\text { Post:normal }\end{array}$ & $\begin{array}{l}\text { Pre:56.6 } \\
\text { Post:normal }\end{array}$ & $\begin{array}{l}\text { BEP } \times 3 \\
\text { cycles }\end{array}$ \\
\hline $\begin{array}{l}\text { 21.lo'pez- } \\
\text { arias et al. } \\
\text { [13] }\end{array}$ & 1 & 28 & $\begin{array}{l}\text { abdominal pain, a } \\
\text { right adnexal mass }\end{array}$ & RSO & $13, \mathrm{CS}$ & $\begin{array}{l}\text { retiform } \\
\text { /Hepat }\end{array}$ & Hepat & $\begin{array}{l}\text { NA( without } \\
\text { virilization) }\end{array}$ & $\begin{array}{l}\text { Pre:636 } \\
\text { Post } \\
\text { 1W:150 } \\
\text { Post } \\
\text { 5M:0.89 }\end{array}$ & NA \\
\hline $\begin{array}{l}\text { 22.Liggins } \\
\text { et al.[14] }\end{array}$ & 1 & 40 & $\begin{array}{l}\text { progressive left } \\
\text { lower abdominal } \\
\text { pain } 5 y\end{array}$ & BSO & 13 & $\begin{array}{l}\text { NA } \\
\text { /Hepat }\end{array}$ & $\begin{array}{l}\text { Hepat, } \\
\text { carcinoid } \\
\text { tumor }\end{array}$ & NA & $\begin{array}{l}\text { Pre:NA but } \\
\text { elevated } \\
\text { Post:normal }\end{array}$ & $\begin{array}{l}\text { carboplé } \\
\text { and } \\
\text { paclitax } \\
\text { x2 cycle }\end{array}$ \\
\hline $\begin{array}{l}\text { Present } \\
\text { Case }\end{array}$ & 1 & 18 & $\begin{array}{l}\text { Right lower } \\
\text { abdominal pain }\end{array}$ & LSO & $\begin{array}{l}15 \times 12 \times \\
11, C S\end{array}$ & $\begin{array}{l}\mathrm{PD} \\
/ \mathrm{IME}\end{array}$ & $\begin{array}{l}\text { IME, } \\
\text { Lipoblastoma }\end{array}$ & Normal & $\begin{array}{l}\text { Pre: } 442.6 \\
\text { Post 5M: } \\
1.9\end{array}$ & $\begin{array}{l}\text { DP } \times 10 \\
\text { cycles }\end{array}$ \\
\hline
\end{tabular}

Up to now, there is no uniformly accepted treatment for ovarian SLCTs[33], and surgical excision is the preferred treatment of choice[34]. Unilateral adnexectomy or ovarian cystectomy can result in favorable clinical outcomes in early-stage or highly differentiated SLCT patients who wished to retain fertility $[35,36]$; while advanced or poorly differentiated SLCT patients may benefit more from unilateral adnexectomy + staging operations such as omentectomy, appendectomy and lymphadenectomy of the pelvic cavity. The combination of chemotherapy and cellular immunity can be considered after the surgery. Despite this, controversy still exists about the necessity of lymphadenectomy of the pelvic cavity.Brown et al.[37] showed that a lymph node metastasis was rare in SCSTs, thus indicating that lymphadenectomy could be omitted when staging patients with ovarian SCSTs. Young and Scully found that $19 \%$ of tumors with heterologous elements were considered malignant clinically[1].Postoperative chemotherapy is generally required in patients with poor prognosis such as advanced tumors, moderately or poorly differentiated tumors, presence of heterologous elements, and tumor rupture [3, 1, 2, 7],but its efficacy needs to be further evaluated in clinical trails[34, 33, 7, 14]. The combination of bleomycin, etoposide and cisplatin (BEP) is regarded as standard chemotherapy of SCSTs[38, 39], and other chemotherapy regimens include cisplatin, doxorubicin and cyclophosphamide (CAP), and cisplatin, vinblastine and bleomycin (PVB)[40].Currently, there is no chemotherapy regimen specifically for heterologous elements in SCSTs. No specific treatment is required for patients in whom gastrointestinal type mucinous epithelium has no significant effect on the prognosis, but it remains unknown whether it is required for malignant interstitial cell tumors with heterologous elements. Further well-designed and large-sample clinical trials are warranted to investigate the effects of age, fertility potential and presence of heterologous elements. In this case, unilateral adnexectomy was performed in the first surgery (her fertility was retained) but lymph nodes were not removed, and DP chemotherapy was administered for 6 cycles and triptorelin was injected to preserve her ovarian function. The patient became naturally pregnant 3 years after the surgery. Unfortunately, tumor recurred in the opposite ovary. Ovarian cystectomy was performed, and future surgery and auxiliary chemotherapy were scheduled at an appropriate time in order to improve the long-term survival of the patient.

Postoperative adjuvant chemotherapy is recommended for ovarian SLCTs with heterologous elements, but it would cause irreversible ovarian damage and even premature ovarian failure in young patients, which highlights the need to preserve ovarian function before and after chemotherapy[1-3]. The DOC and DDP used in this case may directly or indirectly affect the maturation and development of oocytes and even cause premature ovarian failure[41, 42]. It is reported that the use of gonadotropin-releasing hormone $(\mathrm{GnRH})$ agonist before DOC chemotherapy could result in a $86.8 \%$ reduction in docetaxel-induced ovarian damage[43].In our case, triptorelin was injected to preserve the ovarian function of the patient, which could arrest the development and maturation of primordial follicles during chemotherapy and reduce the damage to the ovary and the sensitivity to cytotoxic drugs, and consequently contributed to preserve 
the ovarian function[44] and reduce the risk of premature ovarian failure of the patient. A full-term baby was born, indicating that the administration of GnRH-a during operation can be useful to preserve the ovarian function.

In general, ovarian SLCTs are relatively inactive with a detection rate of $18 \%$. It has been reported that all well differentiated tumors were benign, and $11 \%$ of moderately differentiated tumors, $59 \%$ of poorly differentiated tumors and $19 \%$ of tumors were malignant[1].The long-term prognosis is closely associated with clinical stage, tumor size, differentiation degree, cell proliferation index, tumor rupture and presence or absence of heterologous elements, and those patients with tumors of $>15 \mathrm{~cm}$, poorly differentiated tumors, nuclear division and a reticular pattern are likely to have poorer prognosis [33, 45].The 5-year survival rate was $100 \%$ in patients with highly differentiated ovarian SLCTs but only $80 \%$ in patients with poorly differentiated ovarian SLCTs. It has also been reported that the survival rate was $95 \%$ in stage $₫$ patients but almost 0 in stage $\varangle / I V$ patients[1, 14].The gastrointestinal type epithelium has no significant effect on the prognosis, but malignant stromal components such as rhabdomyosarcoma and chondrosarcoma can result in poor prognosis[46-48]. Thus, there is a need for more intensive follow up for those ovarian SLCT patients with heterologous elements, which will significantly contribute to early detection and treatment. In our case, the patient was diagnosed to have stage $₫ \mathrm{c}$ ovarian SLCT with liposarcoma and a large ruptured mass was found during the surgery, all of which were considered poor prognostic factors. The patient was closely followed up for 2 years but lost to follow up for 1 year. However, recurrence occurred in the opposite ovary during the early pregnancy three years after the operation, but happily a full-term baby was born. The mass of the right ovary was removed and no recurrence was found at 6-month follow up. It is evident that these favorable outcomes are of importance for the patient and her famlily members.

\section{Conclusion}

In summary, we reported a rare ovarian SLCT case with mucinous epithelium and liposarcoma, and proposed that the increase in serum AFP levels was probably associated with the presence of heterologous elements, which could be used for preoperative diagnosis of the presence of heterologous elements and the postoperative recurrence. Conservative surgery can be performed in early stage young patients in order to retain their fertility, whereas radical hysterectomy and bilateral adnexectomy can be performed in patients with menopause or poorly differentiated tumors. Importantly, large-sample long-term follow up studies are warranted in high-risk patients with tumor rupture before surgery and evident metastatic lesions, especially patients with heterologous elements in which controversy still exists regarding the necessity of specific chemotherapy, in order to better predict the prognosis and determine the specificity of heterologous elements in these patients. GN can be used during chemotherapy to protect ovarian function in order for patients to become pregnant.

\section{Abbreviations}

Sur:Surgery performed

Clinical:Clinical manifestations

G:Gross

Chemo:Chemotherapy and regimen

Differ/AFP(+) :differentiation /Localization of AFP in Tumor

Heter:Heterologus elements

BVC:bleomycin,Vinblastin and cisplatin

Cy-actD-D:cyclophosphamide,actinomycin-D and doxorubicin

Cy-actD-V:cyclophosphamide,actinomycin-D and Vinblastin

BEP:bleomycin,etoposide,and cisplatin;AFP:alpha fetoprotein

SLCT:Sertoli-Leydig cell tumors

RSO:right salpingo-oophorectomy

LSO:left salpingo-oophorectomy

BSO:bilateral salpingo-oophorectomy

TAH:total abdominal hysterectomy

GIEP:gastrointestinal-type epithelium

IME:intestinal-type mucinous epithelium

SM:skeletal muscle

R-Sar:Rhabdomyosarcoma 
Hepat:hepatocytes

A\&W:alive and well

W:Weeks

M:Mouth

WD:well differentiated

MD:moderately differentiated

PD:poorly differentiated

MPD:moderately to poorly diferentiated

Pre:Preoperative

Post:Postoperative

$\mathrm{T}:$ Testosterone

CS:cystic and solid mass

R:right adnexa

NA:Not available

Post 2nd:the second Postoperative

Re:Recurrence

\section{Declarations}

\section{Conflict of Interest}

The authors declare that they have no conflict of interest.

\section{Ethics Approval}

All procedures performed were ethically approved. All procedures performed were ethically approved.

\section{Consent to Participate}

Informed consent was obtained from all individual participants included in the study.

\section{Consent for Publication}

All involved consented to publication.

\section{Data Availability}

The authors support data transparency.

\section{Code Availability}

N/A

\section{References}

1. Young RH, Scully RE. Ovarian Sertoli-Leydig cell tumors. A clinicopathological analysis of 207 cases. Am J Surg Pathol. 1985;9(8):543-69.

2. Roth LM, Anderson MC, Govan AD, Langley FA, Gowing NF, Woodcock AS. Sertoli-Leydig cell tumors: a clinicopathologic study of 34 cases. Cancer. 1981;48(1):187-97.

3. Zaloudek C, Norris HJ. Sertoli-Leydig tumors of the ovary. A clinicopathologic study of 64 intermediate and poorly differentiated neoplasms. Am J Surg Pathol. 1984;8(6):405-18.

4. McCluggage WG, Young RH. Ovarian Sertoli-Leydig Cell Tumors With Pseudoendometrioid Tubules (Pseudoendometrioid Sertoli-Leydig Cell Tumors). Am J Surg Pathol. 2007;31(4):592-7. doi:10.1097/01.pas.0000213365.56498.72.

5. Mooney EE, Nogales FF, Tavassoli FA. Hepatocytic differentiation in retiform Sertoli-Leydig cell tumors: distinguishing a heterologous element from Leydig cells. Hum Pathol. 1999;30(6):611-7. doi:10.1016/s0046-8177(99)90083-7. 
6. Young RH, Prat J, Scully RE. Ovarian Sertoli-Leydig cell tumors with heterologous elements. I. Gastrointestinal epithelium and carcinoid: a clinicopathologic analysis of thirty-six cases. Cancer. 1982;50(11):2448-56. doi:10.1002/1097-0142(19821201)50:11<2448::aidcncr2820501133>3.0.c0;2-t.

7. Gui T, Cao D, Shen K, Yang J, Zhang Y, Yu Q et al. A clinicopathological analysis of 40 cases of ovarian Sertoli-Leydig cell tumors. Gynecol Oncol. 2012;127(2):384-9. doi:10.1016/j.ygyno.2012.07.114.

8. Prat J, Young RH, Scully RE. Ovarian Sertoli-Leydig cell tumors with heterologous elements. II. Cartilage and skeletal muscle_a clinicopathologic analysis of twelve cases. Cancer. 1982;50(11):2465-75. doi: 10.1002/1097-0142(19821201)50:11<2465::aid-cncr2820501135>3.0.co;2-u.

9. Colombo N, Parma G, Zanagnolo V, Insinga A. Management of ovarian stromal cell tumors. J Clin Oncol. 2007;25(20):2944-51. doi:10.1200/jco.2007.11.1005.

10. Cai SQ, Zhao SH, Qiang JW, Zhang GF, Wang XZ, Wang L. Ovarian Sertoli-Leydig cell tumors: MRI findings and pathological correlation. Journal of ovarian research. 2013;6(1):73. doi:10.1186/1757-2215-6-73

11. Garzo VG, Dorrington JH. Aromatase activity in human granulosa cells during follicular development and the modulation by follicle-stimulating hormone and insulin. Am J Obstet Gynecol. 1984;148(5):657-62.

12. Mooney E, Nogales F, Bergeron C, Tavassoli F. Retiform Sertoli-Leydig cell tumours: clinical, morphological and immunohistochemical findings. Histopathology. 2002;41(2):110-7.

13. Caringella A, Loizzi V, Resta L, Ferreri R, Loverro G. A case of Sertoli-Leydig cell tumor in a postmenopausal woman. Int J Gynecol Cancer. 2006;16(1):4358. doi:10.1111/j.1525-1438.2006.00203.x.

14. Sigismondi C, Gadducci A, Lorusso D, Candiani M, Breda E, Raspagliesi F et al. Ovarian Sertoli-Leydig cell tumors. a retrospective MITO study. Gynecol Oncol. 2012;125(3):673-6. doi:10.1016/j.ygyno.2012.03.024.

15. Zanotti KM. The clinical manifestations and diagnosis of Sertoli-Leydig cell tumors of the ovary. CME Journal of Gynecologic Oncology. 2002;7(2):12933.

16. Lara-Torre E, Dietrich JE, Kaplan A, Lopez H, Jaffee I. A case of poorly differentiated Sertoli-Leydig tumor of the ovary. J Pediatr Adolesc Gynecol. 2004;17(1):49-52. doi:10.1016/j.jpag.2003.11.006.

17. Scully RE. Ovarian tumors. A review. Am J Pathol. 1977;87(3):686-720.

18. Young RH, Scully RE. Ovarian sex cord-stromal tumors: recent progress. Int J Gynecol Pathol. 1982;1(1):101-23.

19. Ayhan A, Tuncer ZS, Hakverdi AU, Yuce K, Ayhan A. Sertoli-Leydig cell tumor of the ovary: a clinicopathologic study of 10 cases. Eur J Gynaecol Oncol. 1996;17(1):75-8.

20. Novak ER, Herman Long J. Arrhenoblastoma of the ovary A review of the Ovarian Tumor Registry. Obstet Gynecol. 1967;30(5):709-15.

21. Hartz PH. Giant cystic arrhenoblastoma of the ovary containing entodermal epithelium and a carcinoid. Am J Pathol. 1945;21(6):1167-91.

22. Fox H. Tumors of the Ovary and Maldeveloped Gonads. J Clin Pathol. 1981;34(1):108-. doi:10.1136/jcp.34.1.108-b.

23. Sirvent N, Coindre JM, Maire G, Hostein I, Keslair F, Guillou L et al. Detection of MDM2-CDK4 amplification by fluorescence in situ hybridization in 200 paraffin-embedded tumor samples: utility in diagnosing adipocytic lesions and comparison with immunohistochemistry and real-time PCR. Am J Surg Pathol. 2007;31(10):1476-89. doi:10.1097/PAS.0b013e3180581fff

24. Binh MB, Sastre-Garau X, Guillou L, de Pinieux G, Terrier P, Lagace R et al. MDM2 and CDK4 immunostainings are useful adjuncts in diagnosing welldifferentiated and dedifferentiated liposarcoma subtypes: a comparative analysis of 559 soft tissue neoplasms with genetic data. Am J Surg Pathol. 2005;29(10):1340-7.

25. Aleixo PB, Hartmann AA, Menezes IC, Meurer RT, Oliveira AM. Can MDM2 and CDK4 make the diagnosis of well differentiated/dedifferentiated liposarcoma? An immunohistochemical study on 129 soft tissue tumours. J Clin Pathol. 2009;62(12):1127-35. doi:10.1136/jcp.2009.070201.

26. Larsen WG, Felmar EA, Wallace ME, Frieder R. Sertoli-Leydig cell tumor of the ovary: a rare cause of amenorrhea. Obstet Gynecol. 1992;79(5 (Pt 2)):831-3.

27. Sengar AR, Kulkarni JN. Growing teratoma syndrome in a post laparoscopic excision of ovarian immature teratoma. J Gynecol Oncol. 2010;21(2):129-31. doi:10.3802/jgo.2010.21.2.129.

28. Cicin I, Eralp Y, Saip P, Ayan I, Kebudi R, lyibozkurt C et al. Malignant ovarian germ cell tumors: a single-institution experience. Am J Clin Oncol. 2009;32(2):191-6. doi:10.1097/COC.0b013e3181841f2e.

29. Talerman A, Haije WG, Baggerman L. Serum alphafetoprotein (AFP) in diagnosis and management of endodermal sinus (yolk sac) tumor and mixed germ cell tumor of the ovary. Cancer. 1987;41(1):272-8. doi:10.1002/1097-0142(197801)41:1<272::aid-cncr2820410138>3.0.co;2-z.

30. Dallenbach P, Bonnefoi H, Pelte MF, Vlastos G. Yolk sac tumours of the ovary: an update. Eur J Surg Oncol. 2006;32(10):1063-75. doi:10.1016/j.ejso.2006.07.010.

31. Watanabe T, Yamada H, Morimura Y, Abe M, Motoyama T, Sato A. Ovarian Sertoli-Leydig cell tumor with heterologous gastrointestinal epithelium as a source of alpha-fetoprotein: a case report. J Obstet Gynaecol Res. 2008;34(3):418-21. doi:10.1111/j.1447-0756.2008.00730.x.

32. Horta M, Cunha TM, Marques RC, Felix A. Ovarian Sertoli-Leydig cell tumor with heterologous elements of gastrointestinal type associated with elevated serum alpha-fetoprotein level: an unusual case and literature review. J Radiol Case Rep. 2014;8(11):30-41. doi:10.3941/jrcr.v8i11.2272.

33. Bhat RA, Lim YK, Chia YN, Yam KL. Sertoli-Leydig cell tumor of the ovary: analysis of a single institution database. J Obstet Gynaecol Res. 2013;39(1):305-10. doi:10.1111/j.1447-0756.2012.01928.x.

34. Weng CS, Chen MY, Wang TY, Tsai HW, Hung YC, Yu KJ et al. Sertoli-Leydig cell tumors of the ovary: a Taiwanese Gynecologic Oncology Group study. Taiwan J Obstet Gynecol. 2013;52(1):66-70. doi:10.1016/j.tjog.2012.03.001. 
35. Gheorghisan-Galateanu A, Fica S, Terzea DC, Caragheorgheopol A, Horhoianu V. Sertoli-Leydig cell tumor - a rare androgen secreting ovarian tumor in postmenopausal women. Case report and review of literature. J Cell Mol Med. 2003;7(4):461-71. doi:10.1111/j.1582-4934.2003.tb00249.x.

36. Gershenson DM. Management of early ovarian cancer: germ cell and sex cord-stromal tumors. Gynecol Oncol. 1994;55(3 Pt 2):S62-72.

37. Brown J, Sood AK, Deavers MT, Milojevic L, Gershenson DM. Patterns of metastasis in sex cord-stromal tumors of the ovary: can routine staging lymphadenectomy be omitted? Gynecol Oncol. 2009;113(1):86-90. doi:10.1016/j.ygyno.2008.12.007.

38. Chen FY, Sheu BC, Lin MC, Chow SN, Lin HH. Sertoli-Leydig cell tumor of the ovary. J Formos Med Assoc. 2004;103(5):388-91.

39. Sachdeva P, Arora R, Dubey C, Sukhija A, Daga M, Singh DK. Sertoli-Leydig cell tumor: a rare ovarian neoplasm. Case report and review of literature. Gynecol Endocrinol. 2008;24(4):230-4. doi:10.1080/09513590801953465.

40. Roth BJ, Greist A, Kubilis PS, Williams SD, Einhorn LH. Cisplatin-based combination chemotherapy for disseminated germ cell tumors: long-term followup. J Clin Oncol. 1988;6(8):1239-47. doi:10.1200/jco.1988.6.8.1239.

41. Lopes F, Smith R, Anderson RA, Spears N. Docetaxel induces moderate ovarian toxicity in mice, primarily affecting granulosa cells of early growing follicles. Mol Hum Reprod. 2014;20(10):948-59. doi:10.1093/molehr/gau057.

42. Morgan S, Lopes F, Gourley C, Anderson RA, Spears N. Cisplatin and doxorubicin induce distinct mechanisms of ovarian follicle loss; imatinib provides selective protection only against cisplatin. PLoS One. 2013;8(7):e70117. doi:10.1371/journal.pone.0070117.

43. Park I, Lee S, Ryu KJ, Min KJ, Hong JH, Song JY et al. A gonadotropin-releasing hormone agonist for the prevention of docetaxel-induced gonadal damage. J Obstet Gynaecol. 2017;37(6):783-9. doi:10.1080/01443615.2017.1306839.

44. Kurman RJ, Shih le M. The Dualistic Model of Ovarian Carcinogenesis: Revisited, Revised, and Expanded. Am J Pathol. 2016;186(4):733-47. doi:10.1016/j.ajpath.2015.11.011.

45. Haroon S, Zia A, Idrees R, Memon A, Fatima S, Kayani N. Clinicopathological spectrum of ovarian sex cord-stromal tumors; 20 years' retrospective study in a developing country. Journal of ovarian research. 2013;6(1):87. doi:10.1186/1757-2215-6-87.

46. Soleimanpour H, Shirian S, Oryan A, Daneshbod K, Bagheri N, Daneshbod Y. Cytologic, immunocytologic, histopathologic and immunohistologic diagnosis of the poorly differentiated sertoli-leydig cell tumor. Acta Cytol. 2011;55(4):382-6. doi:10.1159/000327906.

47. Rekhi B, Karpate A, Deodhar KK, Chinoy RF. Metastatic rhabdomyosarcomatous elements, mimicking a primary sarcoma, in the omentum, from a poorly differentiated ovarian Sertoli-Leydig cell tumor in a young girl: an unusual presentation with a literature review. Indian J Pathol Microbiol. 2009;52(4):5548. doi:10.4103/0377-4929.56165.

48. Singh ZN, Singh MK, Chopra P. Sertoli Leydig Cell Tumor with Malignant Heterologous Elements and Raised Alpha-Fetoprotein_A Case Report. J Obstet Gynaecol Res. 1996;22(6):595-8.

\section{Figures}



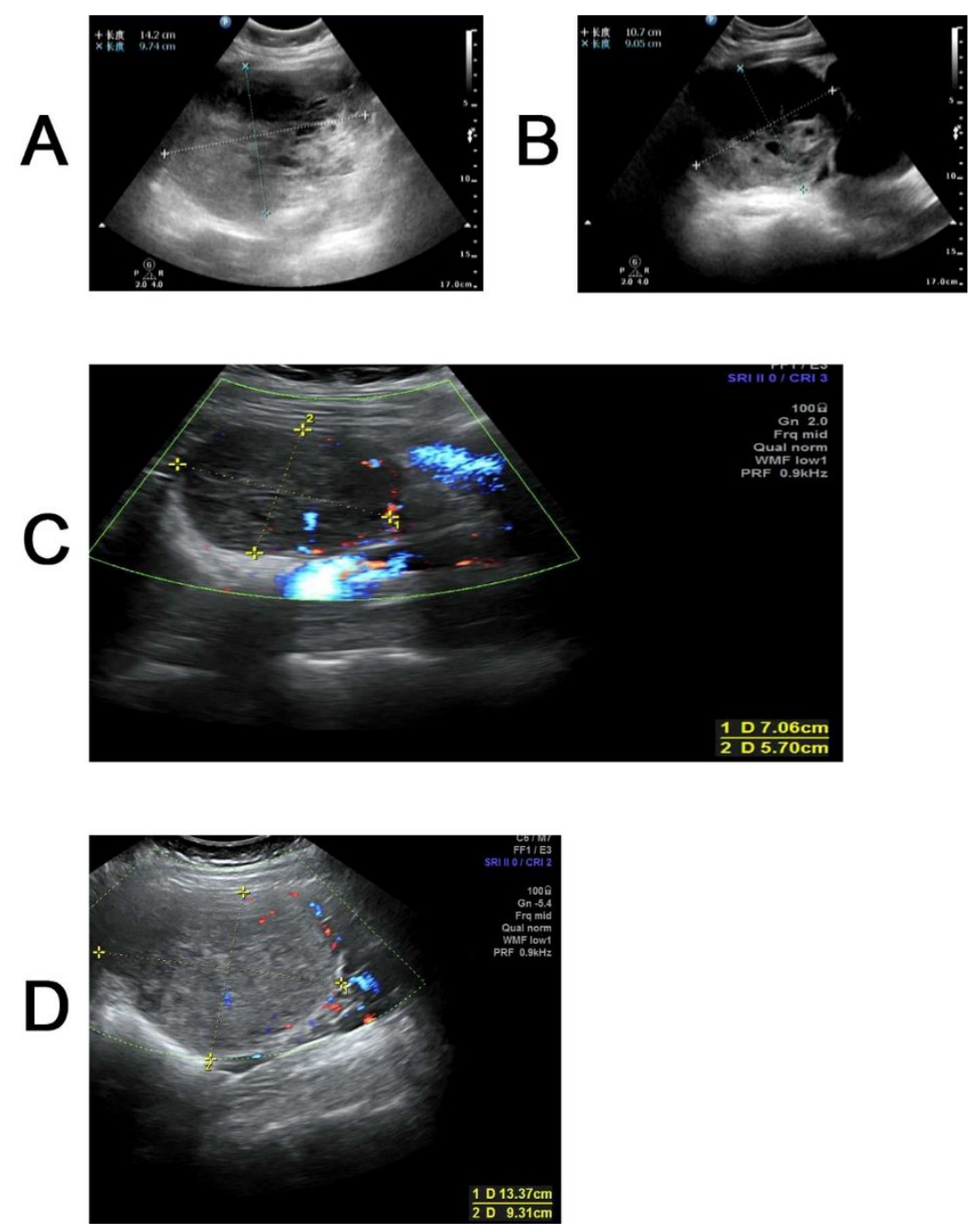

Figure 1

B-Ultrasound images of ovarian mass in $2015(\mathrm{a}, \mathrm{b})$ and 2017 (c, d) A:A solid-cystic mass of approximately $14.2 \times 10.5 \times 9.7 \mathrm{~cm}$ is observed in the right lower quadrant of the abdomen, which has a clear boundary but an irregular shape. Some solid areas, cystic areas and small segments are observed. B:A solidcystic mass of approximately $10.7 * 10.2 * 9.1 \mathrm{~cm}$ is observed in the right upper quadrant of the uterus, which has a clear boundary and several small follicles. C: Low echo is observed on the right side of the ovary on January 28,2019 , which is approximately $7.3 \times 5.7 \mathrm{~cm}$ and has a clear boundary and regular shape. Color Doppler flow imaging (CDFI) reveals streak blood stream signals. D: A solid-cystic (mainly solid) mass is observed in the right adnexal area on April 8 , 2019 , which is approximately $13.4 \times 10.7 \times 8.4 \mathrm{~cm}$ and has a clear boundary and regular shape. CDFI reveals streak blood stream signals in the solid area. 

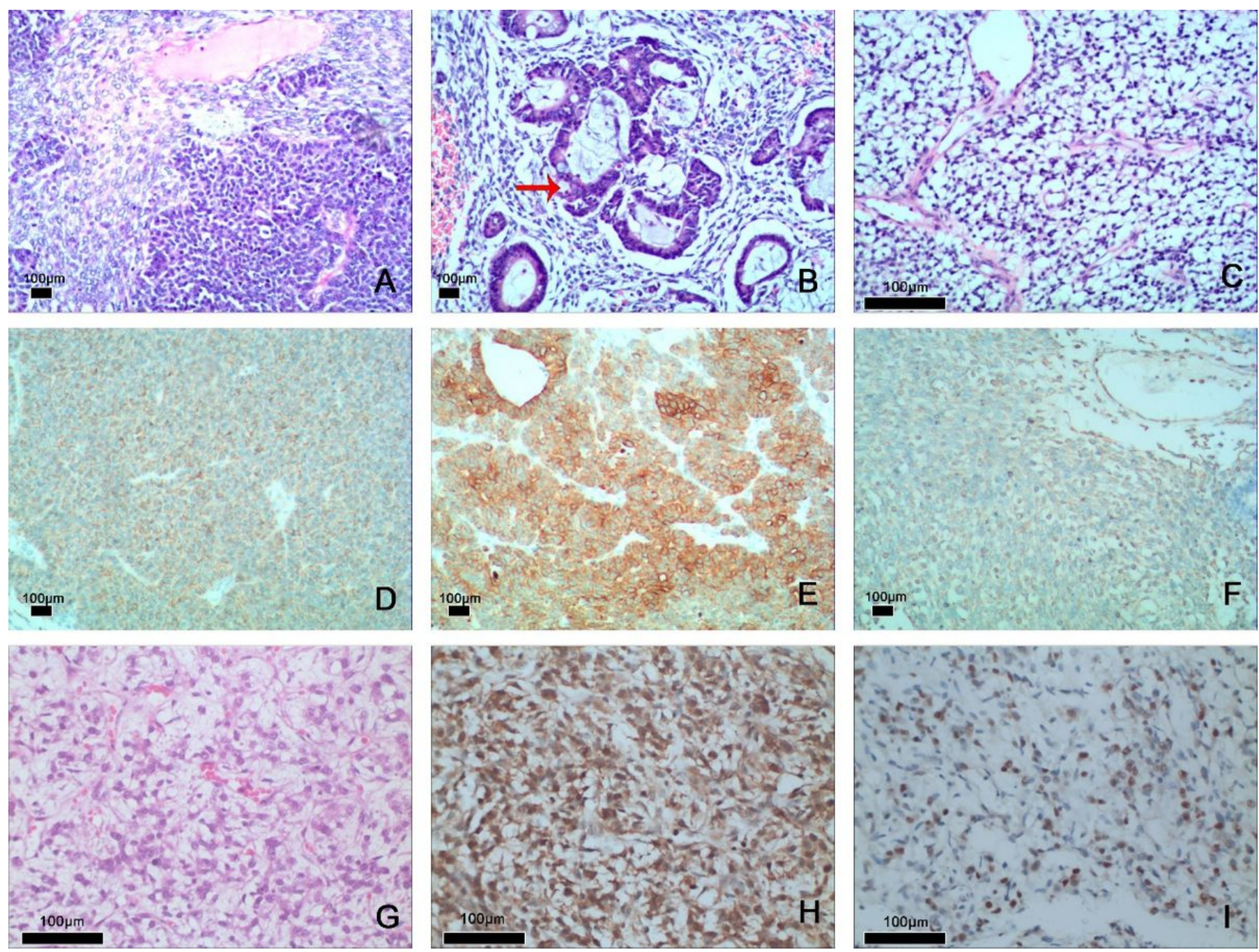

\section{Figure 2}

HE and immunohistochemical staining A. Sertoli cells: poor differentiation, nuclear pleomorphism, flaky distribution, no tubular structure; Lerdig cells: rich eosinophilic cytoplasm (HEx100). B. Intestinal type mucinous epithelium: glands are well formed goblet cells are occasionally seen, as indicated by red arrows (HEx100). C. Liposarcoma: there is a large number of monocytes with fatty vacuoles, and their nuclei are pushed to the periphery by vacuoles, giving the cell a typical signet ring appearance. Capillary networks are also observed (HEx400). D. CD99(+) in tumor tissues (IHCx100). E. CK(+) in tumor tissues (IHCx100). F. Vimentin(+) in tumor tissues (IHCx100). G. Liposarcoma: there is a large number of naive adipocytes with deeply stained nuclei and capillary network(HEx400). H. Liposarcoma. MDM2 is positively stained (IHC x400). I. Liposarcoma CDK44 is positively stained (IHCx400). 
Follow-up of Alpha-fetoprotein(AFP) levels ( $\mathrm{ng} / \mathrm{ml}$ )

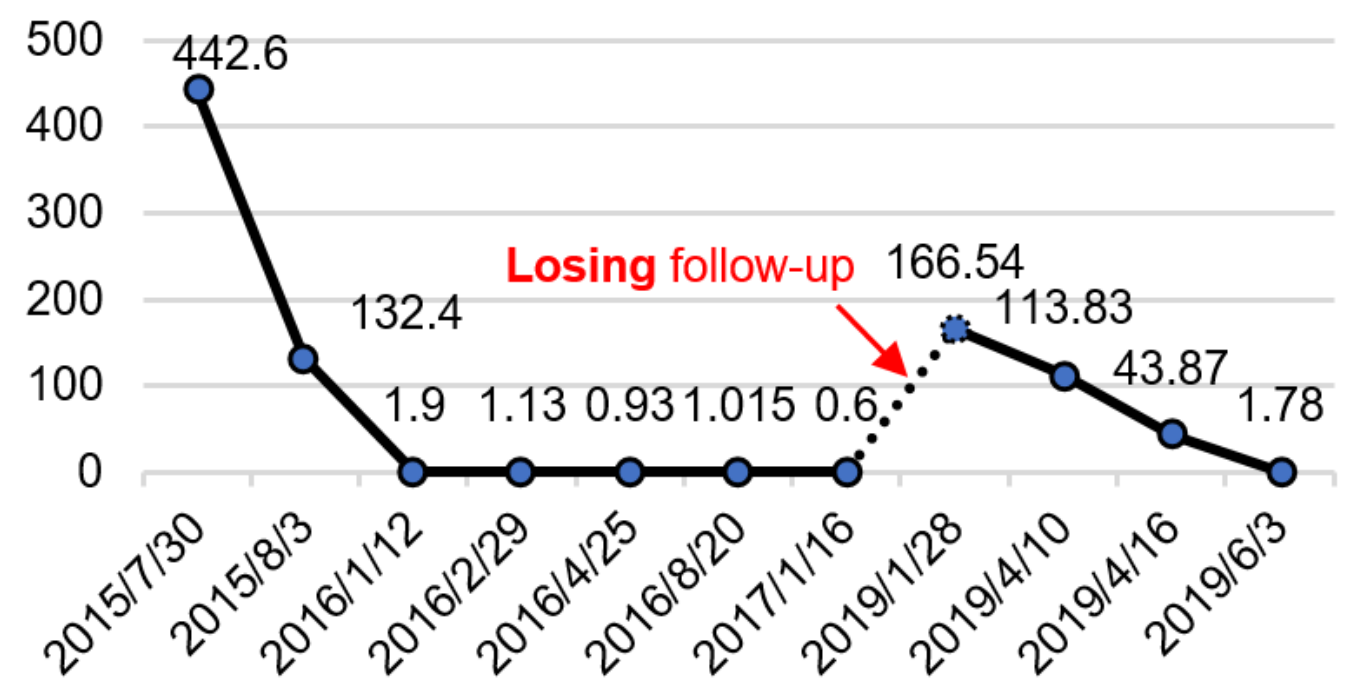

Figure 3

Changes in serum AFP levels (red arrow indicates lost in follow up)

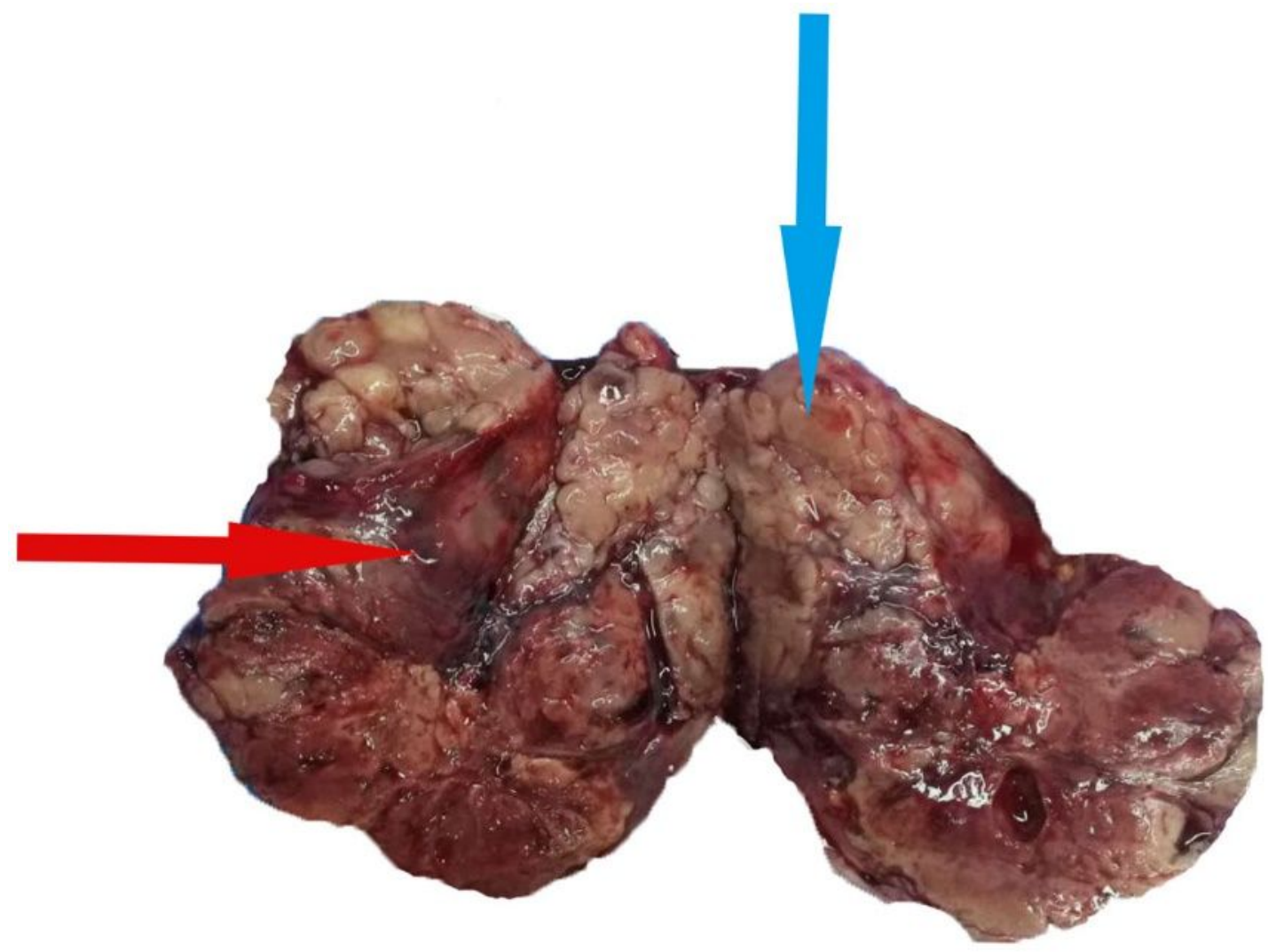




\section{Figure 4}

Macroscopic specimen shows a grey brown, solid-cystic mass: $(\rightarrow)$ cystic area and $(\downarrow)$ solid area
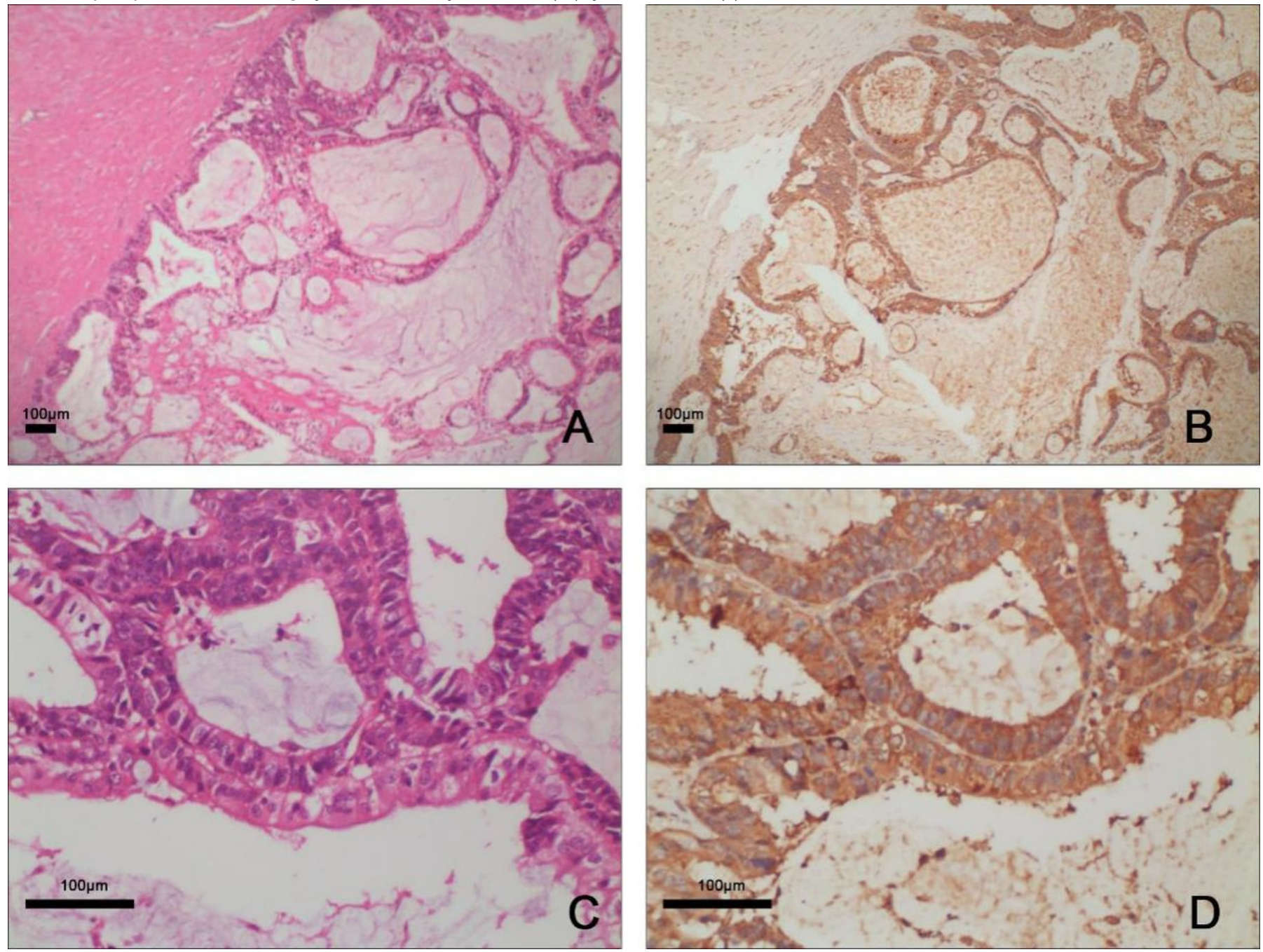

\section{Figure 5}

HE staining $(A, C)$ of mucus epithelium and strong positive immunohistochemical staining for $A F P(B, D)$ at the corresponding sites $A$ and $B$. HE staining showed mucus epithelium under low power microscopy, and immunohistochemical staining showed positive staining for AFP at the corresponding sites (x100). C and D. HE staining showed mucus epithelium under high power microscopy, and immunohistochemical staining showed positive staining for AFP at the corresponding sites ( $x 400)$.

\section{Supplementary Files}

This is a list of supplementary files associated with this preprint. Click to download.

- CARECheckist.docx 